\title{
REMASTERING SISTEM OPERASI BERBASIS OPEN SOURCE LINUX UNTUK PEMBELAJARAN KIMIA (STUDI KASUS PADA MATA KULIAH KOMPUTASI DATA JURUSAN ANALIS KIMIA UNDIKSHA)
}

\author{
Ni Wayan Martiningsih ${ }^{1}$ dan I Made Gede Sunarya ${ }^{2}$. \\ 1 Jurusan Analis Kimia Fakultas Matematika dan IImu Pengetahuan Alam \\ 2Jurusan Pendidikan Teknik Informatika Fakultas Teknik dan Kejuruan \\ Universitas Pendidikan Ganesha \\ Singaraja, Bali \\ E-mail:marti_chem03@yahoo.co.id ${ }^{1}$, imadegedesunarya@gmail.com²
}

\begin{abstract}
Abstrak
Penelitian ini bertujuan untuk merancang pengembangan remastering sistem operasi berbasis open source linux untuk pembelajaran kimia pada mata kuliah Komputasi Data dan mengetahui respon mahasiswa terhadap remastering sistem operasi tersebut. Rancangan yang digunakan dalam penelitian ini adalah rancangan penelitian pengembangan (Research and Development). Pengumpulan data respon mahasiswa dilakukan dengan cara pemberian angket kepada mahasiswa. Data yang terkumpul dianalisis secara statistik deskriptif.

Rancangan remastering dilakukan berdasarkan analisis kebutuhan pada mata kuliah Komputasi Data. Remastering dirancang menggunakan Linux Ubuntu 10.4 dan menggabungkan program aplikasi kimia yaitu Avogadro, Bkchen, Chemical calculator, dwawXTL, GabEdit, GchemPaint, Gperiodic, Kalzium, PeriodicTable, XdrawChem. Respon mahasiswa terhadap pengembangan remastering sistem operasi linux untuk pembelajaran kimia pada mata kuliah Komputasi Data adalah sangat positif.
\end{abstract}

Kata kunci : remastering, open source, pembelajaran kimia

\section{Abstract}

This study aims to design a remastering development based on open source operating system Linux for chemistry learning on Data Computational course and study the response of students to the remastering of the operating system. The design used in this research is the study design development (Research and Development). Student response data collection is done by giving questionnaires to students. The collected data were analyzed by descriptive statistics.

The design of remastering done based on the needs analysis Data Computational courses. Remastering was designed using Ubuntu Linux 10.4 and combines chemical application program that is Avogadro, Bkchen, Chemical calculator, dwawXTL, GabEdit, GchemPaint, Gperiodic, Kalzium, PeriodicTable, XdrawChem. Student response to the development of remastering a linux operating system for teaching chemistry in Data Computing courses is very positive.

Keywords: remastering, open source, learning chemistry 


\section{PENDAHULUAN}

Pendidikan memegang peranan yang
amat penting untuk menjamin kelangsungan hidup negara dan bangsa, karena pendidikan merupakan wahana untuk meningkatkan dan mengembangkan kualitas sumber daya manusia. Seiring dengan perkembangan teknologi komputer dan teknologi informasi, maka dunia pendidikan pun tidak lepas dari pengaruh perkembangan tersebut. Dalam kegiatan belajar mengajar, komputer telah menjadi bagian yang tidak dapat diabaikan. Bahkan kegiatan belajar mengajar yang ditunjang dengan pemanfaatan teknologi komputer telah dapat meningkatkan hasil belajar peserta didiknya.

Jurusan Analis Kimia merupakan jurusan non kependidikan yang berada di bawah Fakultas Matematika dan IImu Pengetahuan Universitas Pendidikan Ganesha. Pada kurikulum Jurusan Analis Kimia terdapat mata kuliah Komputasi Data yang mempelajari aplikasi komputer umum dan yang berkaitan dengan pembelajaran kimia. Permasalahan yang dihadapi pada proses pembelajaran sebelumnya adalah software bidang kimia harus selalu diinstal di komputer laboratorium dalam setiap proses perkuliahan karena bukan merupakan software yang umum digunakan. Proses instalasi ini menyebabkan proses pembelajaran menjadi terhambat. Software bidang kimia yang digunakan dalam kegiatan belajar mengajar selama ini adalah software ilegal karena mahalnya biaya pembelian lisensi software. Pemakaian software ilegal bukan merupakan solusi yang baik mengingat pembajakan hasil karya orang lain adalah merupakan kejahatan intelektual. Alternatif penggunaan software secara legal tanpa membeli sebuah lisensi adalah penggunaan software open source.

Software open source adalah peranti lunak yang disediakan untuk digunakan, dimodifikasi dan didistribusi ulang. Peranti lunak ini tidak memiliki batasan-batasan dari pemegang hak cipta mengenai modifikasi perintah-perintah internalnya dan distribusi ulangnya. Piranti lunak berlisensi open source selalu didistribusikan atau dapat diakses bersama-sama dengan kode asalnya, umumnya secara gratis. Piranti lunak ini biasanya disalah-artikan sebagai freeware. Keduanya tidaklah sama, karena ada perbedaan yang mendasar antara model lisensi dan proses yang terjadi pada kedua jenis piranti lunak tersebut. Software open source memiliki karakteristik utama, yaitu bebas didistribusikan dan didistribusikan ulang, kode sumber tersedia secara umum, kode sumber bisa dimodifikasi dan didistribusikan ulang, tidak ada diskriminasi perorangan atau kelompok (Georgescu, 2010).

Penerapan open source pada tahuntahun belakangan ini mengalami perkembangan yang sangat pesat. Penerapan open source sudah diberdayagunakan dalam kegiatan universitas (Agus, 2009) (Havilludin, 2010) (Alifuddin, 2010) yang bertujuan untuk menghindari suatu pelanggaran etika dan Hak Cipta. Hal ini sejalan dengan tujuan Mendiknas R.I yang tertuang dalam Permendiknas No. 38/2008; Pasal 6 ayat 1 yaitu Sistem dan aplikasi yang digunakan oleh Departemen baik pada server maupun pada pengguna (user) adalah sistem dan aplikasi legal sesuai peraturan perundangundangan, dapat bersifat proprietary dan/atau non-proprietary (open source). Pemanfaatan software open source dalam pengelolaan perpustakaan sekolah atau universitas (Neelakandan, 2010), dalam bidang kesehatan dengan pengembangan E-Health berbasis open source (Supriyatno, 2006), dalam bidang pemerintahan dengan dikembangkannya web berbasis open source (Hartono, 2010), dalam bidang implementasi jaringan komputer (Almaadin, 2010) (Ismail, 2010), dalam sistem kolaborasi (Ciurea, 2010), dalam bidang pengembangan website berbasis content management system (Tănasie, 2010), dalam bidang pembelajaran dan Elearning(Amhadi, 2010).

Software open source dalam bidang kimia telah banyak dikembangkan, baik dalam flatform Microsoft Windows maupun Linux. Beberapa software open source bidang kimia pada platform linux ubuntu adalah jMol, MolWork, Xdrawchem, Gchempaint, Chemtool, Openbabel, Chemeq, Easychem, Bkchem, Autodock, 
Gperiodic, gElemental, xmaketool, horae, Pada platform linux varian Ubuntu, secara umum program aplikasi dapat dijalankan tanpa melalui proses instalasi karena linux mempunyai mode live cd, dimana sistem operasi linux dijalankan melalui optical drive (CD/DVD). Program aplikasi dalam bidang kimia tidak secara umum terdapat pada sebuah komputer, sehingga perlu dilakukan proses penambahan program aplikasi tersebut. Dengan adanya teknologi live cd dari linux, memungkinkan dibuatnya sebuah varian linux ubuntu yang berisi beberapa aplikasi kimia yang dijalankan tanpa proses instalasi. Berdasarkan permasalahan terbatasnya resource program bidang kimia yang terinstal dalam komputer dan terdapatnya software open source pada sistem operasi linux ubuntu, maka penulis melakukan penelitian pengembangan dengan judul Remastering Sistem Operasi Berbasis Open source Linux untuk Pembelajaran Kimia (Studi Kasus Pada Mata Kuliah Komputasi Data Jurusan Analis Kimia UNDIKSHA).

\section{KAJIAN TEORI}

\section{a. Remastering}

Remastering adalah Perombakan atau modifikasi sistem operasi (SO) dimana kita bisa menambah, mengubah dan menghapus fitur-fitur yang ada di SO. Remastering bahkan bisa memperindah tampilan sistem operasi sesuai dengan keinginannya masing-masing. Cara yang digunakan untuk remastering ubuntu ada 2 macam dengan custom live cd dan dengan backup. Proses yang terjadi pada saat remastering adalah (Sulaeman, 2010) :

a. Pembaharuan paket yang sudah ada pada ubuntu 10.04.

b. Penambahan aplikasi yang dibutuhkan.

c. Pengurangan aplikasi yang tidak dibutuhkan.

d. Perubahan tampilan keseluruhan.

Remastering sendiri sebenarnya adalah proses membuat master baru untuk sebuah album, film, atau ciptaan lainnya dari hasil cipta yang sebelumnya sudah ada. seperti pada proses memindahkan rekaman musik yang berasal dari media analog menjadi rekaman digital (hal ini lebih dikenal pada industri musik dan film), namun seiring dengan waktu istilah remaster tidak saja menjadi milik industri film dan musik, seperti halnya penggunaan istilah Virus Biologis pada bidang medis dan penggunaan istilah Virus Komputer pada industri software. Penggunaan istilah remaster pada linux sendiri mulai dipopulerkan oleh Klaus Knopper sang pencipta Distro Linux LiveCD-Knoppix yang mana Knoppix sendiri merupakan hasil remaster dari Debian.

Dalam bidang software remastering dapat diartikan sebagai sebuah proses pembungkusan ulang paket aplikasi pada sistem operasi dimana kita bisa menambah bahkan bisa juga mengurangi paket aplikasi yang disertakan. Bisa dikatakan bahwa remastering merupakan proses pembuatan sistem operasi baru dengan paket aplikasi yang berbeda dari sistem aslinya (default). Dengan remastering memungkinkan kita untuk menambah atau mengurangi paket aplikasi di sistem operasi yang ada dengan paket aplikasi yang baru. Istilah lain yang biasanya digunakan adalah operating system deployment atau slipstream istilah ini biasanya dikenal di lingkungan windows, dimana sebuah Sistem windows yang telah ada ditambahkan driver ataupun software tambahan dibundel kembali menggunakan imaging software atau wim image.

Software remastering adalah sebuah software yang digunakan dalam proses memaketkan ulang sistem operasi dalam hal ini menambah atau mengurangi paket yang ada bahkan pada beberapa software memiliki fitur sampai pada level tampilan pengguna dimana kita bisa mengubah style, theme standar dari sistem operasi tersebut.

b. Linux

Linux merupakan sistem operasi bertipe Unix modular. Linux memiliki banyak disain yang berasal dari disain dasar Unix yang dikembangkan dalam kurun waktu 1970-an hingga 1980-an. Faktor ketersediaannya dan 
kompatibilitasnya yang tinggi menyebabkannya Unix dapat digunakan, disalin dan dimodifikasi secara luas oleh institusi-institusi akademis dan pada pebisnis. Namun satu hal yang sangat disayangkan pada waktu itu adalah kita tidak bisa sembarangan memodifikasi dan menyebar luaskan Unix secara bebas ke masyarakat umum. Proyek GNU yang mulai pada 1984 memiliki tujuan untuk membuat sebuah sistem operasi yang kompatibel dengan Unix dan lengkap dan secara total terdiri atas perangkat lunak bebas. Tahun 1985, Richard Stallman mendirikan Yayasan Perangkat Lunak Bebas dan mengembangkan Lisensi Publik Umum GNU (GNU General Public License atau GNU GPL).

Kebanyakan program yang

dibutuhkan oleh sebuah sistem operasi (seperti pustaka, kompiler, penyunting teks, shell Unix dan sistem jendela) diselesaikan pada awal tahun 1990-an, namun sayangnya elemen-elemen tingkat rendah seperti device driver, jurik dan kernel masih belum selesai, pada saat itulah (1991) Linus Torvalds mengumumkan telah membuat sebuah kernel yang dibuat berdasarkan Unix yang diberi nama Linux, hal ini tentunya sebuah kebetulan dimana pada waktu itu proyek GNU membutuhkan Kernel (belum memiliki kernel ), hal ini dapat dilihat dari pernyataan Linus Torvalds yang pernah berkata bahwa jika kernel GNU sudah tersedia pada saat itu (1991), dia tidak akan memutuskan untuk menulis versinya sendiri. Keuntungan menggunakan program dan file-file Linux/UNIX (Raharja, 2001) adalah Pada dasarnya semua data tersimpan di dalam harddisk walau ada beberapa kondisi dimana data tersimpan di disket, Ketika program dijalankan, program tersebut dijalankan dari harddisk ke dalam RAM dan setelah dijalankan akan dinamakan sebagai proses, menyediakan servis untuk membuat, memodifikasi program, proses dan file. Linux/UNIX mendukung struktur file yang bersifat hirarki, salah satu sistem operasi yang termasuk ke dalam kelas sistem operasi yang dapat melakukan multitasking, Linux/UNIX juga dapat mendukung multiuser. Kelebihan dari Linux lainnya adalah dapat dilakukannya proses modifikasi terhadap suatu distro Linux sesuai keperluan pengguna. Dalam penelitian ini adalah memodifikasi untuk keperluan pembelajaran kimia.

\section{c. Pembelajaran Komputasi Data}

Mata kuliah Komputasi Data (kode KIA6403) dalam kurikulum Jurusan Analis Kimia merupakan bagian dari kelompok Mata kuliah Perilaku Berkarya (MPB) dengan bobot sks yaitu 2(1). Mahasiswa menempuh mata kuliah ini pada semester tiga. Standar kompetensi dari mata kuliah Komputasi Data adalah mahasiswa mampu mengoperasikan program-program komputer yang berhubungan dengan analisis kimia dan data (Silabus Jurusan Analis Kimia, 2009). Materi pokok yang diajarkan meliputi program-program komputer yang umum digunakan, yaitu Microsoft word, Microsoft excel, Microsoft power point dan SPSS. Selain itu dalam mata kuliah ini juga diajarkan penggambaran struktur molekul senyawa kimia, pengolahan data hasil titrasi asam dan basa serta garam, data hasil kesetimbangan kimia lainnya, data hasil spektroskopi, data hasil kromatografi, data hasil voltametri, dan data dalam kinetika kimia.

\section{METODOLOGI}

\section{a. Uraian Pendekatan}

Metode yang digunakan dalam penelitian ini adalah metode penelitian pengembangan (Research and Development). Desain pengembangan yang digunakan adalah model Dick \& Carey (Santyasa, 2009).

Validasi yang dilakukan untuk produk dari penelitian ini dibagi menjadi 3 tahapan, yaitu :

1. Validasi produk secara teknik, produk yang dihasilkan divalidasi dengan tes pengujian yang dilakukan sesuai formulir penilaian produk

2. Validasi produk oleh para ahli, ahli yang dilibatkan dalam penelitian ini adalah ahli isi dan ahli media. Hasil yang diperoleh dari ahli isi dan ahli media adalah berdasarkan angket yang diberikan kepada ahli media dan ahli isi. 
3. Penerapan terbatas, setelah produk yang dihasilkan divalidasi oleh para ahli, maka produk tersebut diterapkan pada kelompok kecil dan kelompok besar sesuai dengan tahapan pada model pengembangan Dick \& Carey.

\section{b. Subjek dan Objek Penelitian}

Subjek penelitian yang digunakan pada uji terbatas perorangan dan kelompok kecil adalah 12 orang mahasiswa yang sudah pernah mengambil mata kuliah Komputasi Data. Subjek penelitian yang digunakan untuk uji coba lapangan dari produk yang dihasilkan adalah mahasiswa semester IV Jurusan Analis Kimia tahun ajaran 2010/2011 yang sudah mengambil mata kuliah Komputasi Data.

Objek penelitian dalam penelitian ini adalah software open source bidang kimia dan Linux Ubuntu yang diremastering menjadi sebuah sistem operasi Linux Ubuntu dengan varian yang baru. Data respon mahasiswa terhadap pengembangan perangkat lunak remastering linux Ubuntu untuk pembelajaran kimia dikumpulkan dengan menggunakan angket respon.

\section{c. Analisis Data}

Data respon mahasiswa dianalisis dengan menggunakan statistik deskriptif, dan penyimpulannya didasarkan atas Mean Ideal (Mi) dan simpangan baku ideal (Si). Respons mahasiswa digali menggunakan kuesioner dengan skala likert 5 (nilai dari 1 sampai 5) yang dianalisis secara deskriptif. Konversi tingkat respon mahasiswa dapat dilihat pada tabel berikut ini.

Tabel 1. Konversi tingkat respon mahasiswa

\begin{tabular}{|c|c|}
\hline Rentangan Nilai & $\begin{array}{c}\text { Kategori } \\
\text { Respons }\end{array}$ \\
\hline$M_{i}+1,5 S_{i} \leq x$ & Sangat Positif \\
\hline$M_{i}+0,5 S_{i} \leq x<M_{i}+1,5 S_{i}$ & Positif \\
\hline$M_{i}-0,5 S_{i} \leq x<M_{i}+0,5 S_{i}$ & Ragu-ragu \\
\hline$M_{i}-1,5 S_{i} \leq x<M_{i}-0,5 S_{i}$ & Negatif \\
\hline$x<M_{i}-1,5 S_{i}$ & Sangat Negatif \\
\hline
\end{tabular}

Keterangan:

$M_{i}=1 / 2$ (skor tertinggi ideal + skor terendah ideal)

$S_{i}=1 / 6$ (skor tertinggi ideal - skor terendah ideal)

\section{HASIL DAN PEMBAHASAN}

a. Hasil

Analisis perangkat lunak meliputi analisis kebutuhan perangkat lunak, tujuan perangkat lunak, dan model fungsional perangkat lunak. Dari hasil analisis silabus mata kuliah Komputasi Data Jurusan Analis Kimia UNDIKSHA maka diperlukan suatu perangkat lunak yang dapat digunakan untuk membantu proses pembelajaran yang berkaitan dengan penggunaan komputer dalam bidang kimia, seperti tabel periodik, pembuatan struktur kimia. Berdasarkan tujuan yang ingin dicapai pada penelitian ini, perangkat lumak hasil remastering Linux Ubuntu bertujuan untuk dapat dijadikan sebuah media pembelajaran yang dapat membantu dalam penyediaan sistem operasi dan program aplikasi berbasis open source yang digunakan dalam proses pembelajaran dalam mata kuliah Komputasi Data Jurusan Analis Kimia. Program aplikasi merupakan perangkat lunak yang digunakan untuk aplikasi tertentu, dalam hal ini adalah dalam aplikasi kimia. Program aplikasi berjalan pada sebuah sistem operasi, yang dalam hal ini adalah sistem operasi Linux Ubuntu. Berdasarkan analisis kebutuhan perangkat lunak, maka program aplikasi yang digunakan dalam proses remastering adalah Avogadro, Bkchen, Chemical calculator, dwawXTL, GabEdit, GchemPaint, Gperiodic, Kalzium, Periodic Table, XdrawChem, OpenOffice

Perancangan perangkat lunak merupakan proses perancangan dari perangkat lunak sebelum diimplementasikan. Perancangan perangkat lunak terdiri dari perancangan menu dan perancangan GUI (Graphical User Interface). Perancangan menu untuk remastering terdiri dari menu standar dari 
sistem operasi linux Ubuntu dengan ditambahkan dengan program aplikasi opensource dalam bidang kimia yang telah ditentukan pada tahap analisis kebutuhan program aplikasi. Perancangan GUI dilakukan untuk memudahkan pengguna dalam menggunakan aplikasi dan menyesuaikan kebutuhan untuk pembelajaran kimia. Rancangan dari tampilan awal (desktop) dari sistem operasi ditunjukkan pada Gambar 1.

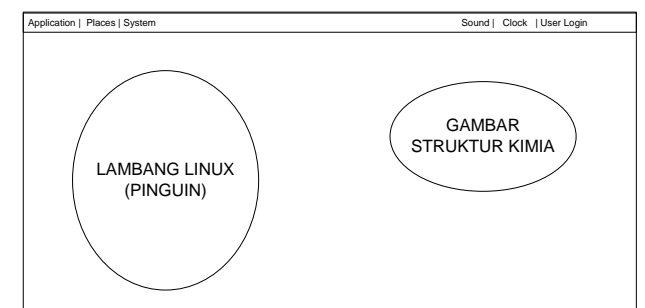

Linux Untuk Pembelajaran Kimia

Gambar 1. Rancangan tampilan awal
remastering

Perangkat lunak hasil remastering ini dikembangakan pada lingkungan sistem operasi linux Ubuntu 10.04 dan menggunakan linux Ubuntu 10.04 sebagai dasar untuk melakukan remastering. Hasil implementasi tampilan awal dari proses remastering ditunjukkan pada Gambar 2.

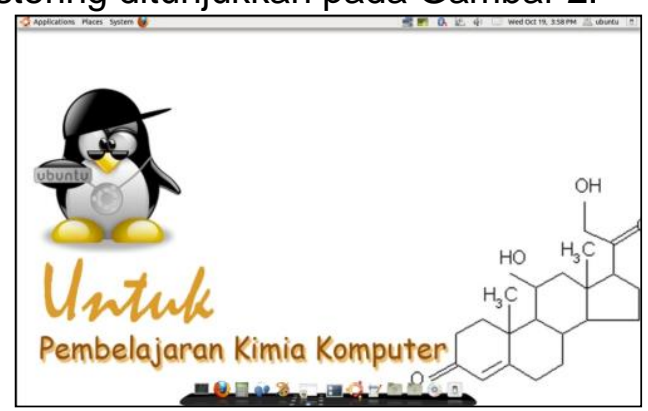

Gambar 2. Tampilan awal hasil remastering

Beberapa hasil implementasi program aplikasi yang terdapat pada perangkat lunak remastering linux Ubuntu ditunjukkan pada Gambar 3.

Pengujian secara teknik perangkat lunak remastering linux Ubuntu untuk pembelajaran kimia ini dilakukan setelah proses implementasi selesai dilakukan. Pengujian ahli media terhadap perangkat lunak remastering linux Ubuntu untuk pembelajaran kimia dilaksanakan dengan memberikan hasil implementasi perangkat lunak remastering linux Ubuntu untuk pembelajaran kimia kemudian dilakukan perbaikan perangkat lunak remastering linux Ubuntu untuk pembelajaran kimia berdasarkan saran-saran yang diberikan oleh para ahli. Pengujian terbatas dilakukan oleh mahasiswa yang memiliki kompetensi dalam bidang komputasi data.

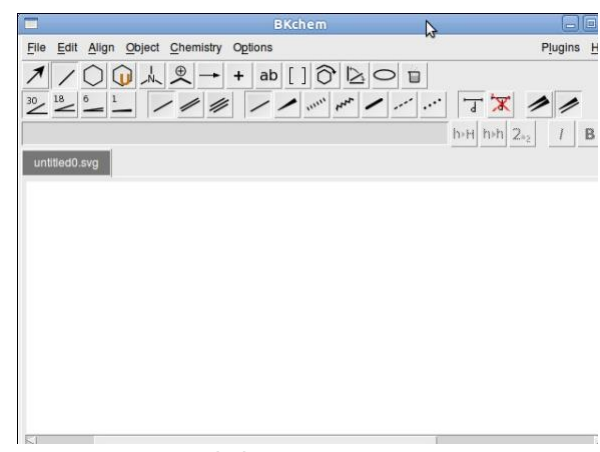

(a)

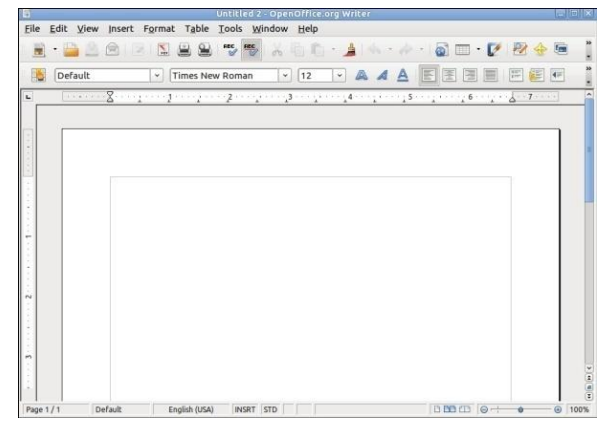

(b)

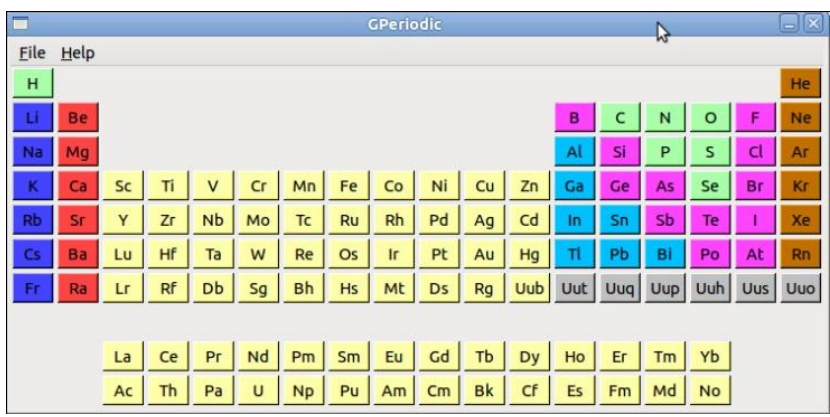

(c)

Gambar 3. Program Aplikasi Remasatering Linux Ubuntu (a. Tampilan Bkchem, b.

Tampilan Open Office Writer, c. Tampilan Gperiodic )

\begin{tabular}{llr}
\multicolumn{1}{c}{ Respon } & mahasiswa & merupakan \\
tanggapan & mahasiswa & terhadap \\
pengembangan & perangkat & lunak \\
remastering linux $\quad$ Ubuntu & untuk \\
pembelajaran kimia sebagai sebuah media
\end{tabular}


dalam membantu pembelajaran di kelas. Angket respon mahasiswa terdiri dari 5 butir pernyataan yang diukur dengan skala linkert 1-5. Skor tertinggi ideal adalah 25 dan skor terendah ideal adalah 5. Rerata respon mahasiswa adalah 43.3 yang menunjukkan secara umum bahwa pengembangan remastering sistem operasi linux untuk pembelajaran kimia dalam kategori sangat positif. Secara rinci dalam tabel adalah sebesar $82.6 \%$ respon dalam kategori sangat positif dan $17.4 \%$ dalam kategori positif.

\section{b. Pembahasan}

Mata kuliah Komputasi Data yang mempelajari aplikasi komputer umum dan yang berkaitan dengan pembelajaran kimia. Permasalahan yang dihadapi pada proses pembelajaran sebelumnya pada mata kuliah tersebut adalah software bidang kimia harus selalu diinstal di komputer laboratorium dalam setiap proses perkuliahan karena bukan merupakan software yang umum digunakan. Proses instalasi ini menyebabkan proses pembelajaran menjadi terhambat. Software bidang kimia yang digunakan dalam kegiatan belajar mengajar selama ini adalah software ilegal karena mahalnya biaya pembelian lisensi software. Pemakaian software ilegal bukan merupakan solusi yang baik mengingat pembajakan hasil karya orang lain adalah merupakan kejahatan intelektual. Alternatif penggunaan software secara legal tanpa membeli sebuah lisensi adalah penggunaan software open source.

Software open source adalah peranti lunak yang disediakan untuk digunakan, dimodifikasi dan didistribusi ulang. Peranti lunak ini tidak memiliki batasan-batasan dari pemegang hak cipta mengenai modifikasi perintah-perintah internalnya dan distribusi ulangnya (Sally, 2007). Piranti lunak berlisensi open source selalu didistribusikan atau dapat diakses bersamasama dengan kode asalnya, umumnya secara gratis. Piranti lunak ini biasanya disalah-artikan sebagai freeware. Keduanya tidaklah sama, karena ada perbedaan yang mendasar antara model lisensi dan proses yang terjadi pada kedua jenis piranti lunak tersebut. Software open source memiliki karakteristik utama, yaitu bebas didistribusikan dan didistribusikan ulang, kode sumber tersedia secara umum, kode sumber bisa dimodifikasi dan didistribusikan ulang, tidak ada diskriminasi perorangan atau kelompok (Georgescu, 2010). Salah satu sistem operasi berbasis open source adalah linux. Dalam sistem operasi linux memungkinkan untuk dilakukannya modifikasi terhadap program-program aplikasi yang terdapat pada sistem operasi linux. Remastering adalah Perombakan atau modifikasi sistem operasi (SO) dimana kita bisa menambah, mengubah dan menghapus fitur-fitur yang ada di SO. Remastering bahkan bisa memperindah tampilan sistem operasi sesuai dengan keinginannya masing-masing. Analisis kebutuhan program aplikasi dilakukkan untuk menentukan kebutuhan jenis-jenis program aplikasi yang diperlukan dalam pembelajaran kimia. Berdasarkan analisis kebutuhan yang dilakukan diperoleh program aplikasi yang diperlukan yaitu, Avogadro, Bkchen, Chemical calculator, dwawXTL, GabEdit, GchemPaint, Gperiodic, Kalzium, PeriodicTable, XdrawChem, OpenOffice. program aplikasi tersebut kemudian diintegrasikan ke dalam linux Ubuntu melalui proses remastering. Proses remastering menghasilkan live CD linux Ubuntu untuk pembelajaran kimia. Live CD yang dihasilkan dapat dipergunakan untuk menjalankan sistem operasi tanpa harus melalui proses instalasi. Dalam live CD sudah terdapat program aplikasi yang digunakan dalam pembelajaran kimia.

Setelah live CD dibuat kemudian dilakukan pengujian terhadap live CD tersebut. Saran-saran yang diberikan oleh para ahli kemudian diakomidasi dengan cara melakukan perubahan-perubahan berdasarkan saran yang diberikan. Hasil dari tahap pengujian ahli, kemudian dilakukan pengujian di kelas untuk mengetahui respon mahasiswa terhadap 
media tersebut. Dengan adanya respon yang sangat positif dari mahasiswa terhadap pengembangan remastering sistem operasi linux untuk pembelajaran kimia pada mata kuliah Komputasi Data maka media ini dapat dimanfaatkan untuk pembelajaran di kelas.

\section{SIMPULAN}

Berdasarkan hasil dan pembahasan penelitian di atas, maka dapat disimpulkan sebagai berikut.

a. Rancangan remastering dilakukan berdasarkan analisis kebutuhan pada mata kuliah Komputasi Data. Remastering dirancang menggunakan Linux Ubuntu 10.4 dan menggabungkan program aplikasi kimia yaitu Avogadro, Bkchen, Chemical calculator, dwawXTL, GabEdit, GchemPaint, Gperiodic, Kalzium, PeriodicTable, XdrawChem.

b. Respon mahasiswa terhadap pengembangan remastering sistem operasi linux untuk pembelajaran kimia pada mata kuliah Komputasi Data adalah sangat positif.

Untuk pengembangan selanjutnya proses remastering dapat dikembangkan untuk membantu proses belajar pembelajaran pada matakuliah dan jurusan lain yang memerlukan spesifikasi perangkat lunak spesifik. media yang digunakan untuk hasil remastering dapat divariasikan tidak hanya sebatas CD/DVD

\section{DAFTAR PUSTAKA}

Agus, F. (2009). Pendayagunaan Open source Software (POSS) Universitas Mulawarman. Jurnal Informatika Mulawarman Vol 4 No. 1 Feb 2009.

Alifuddin, H. M. (2010). Optimalisasi Pemanfaatan Teknologi Informasi Pada Perguruan Tinggi Di Indonesia. Jurnal IT Stmik Handayani Makassar Vol. 01 Desember 2010.

Almaadin, Y. (2010). Rancang Bangun Server Voip Berbasis Metode Parallel Processing. Proceeding Seminar Tugas Akhir Jurusan Teknik Elektro FTI-ITS.
Ciurea, C. (2010). Open source Tools for Collaborative Systems Hierarchization. Open source Science Journal Vol. 2 No. 2, 2010.

Georgescu, M. \& Milodin, D. (2010). Techniques of Improving Open source Software Tools, Open source Science Journal Vol. 2 No. 3, 2010.

Hartono, Utomo, D. \& Mulyanto E. (2010). Electronic Government Pemberdayaan Pemerintahan Dan Potensi Desa Berbasis Web. Jurnal Teknologi Informasi Volume 6 Nomor 1. April 2010. ISSN 1414-9999.

Havilludin. (2010). Pemanfaatan Open source Software (OSS) Dilingkungan Universitas Mulawarman, Jurnal Informatika Mulawarman Vol 5 No. 1 Februari 2010.

Ismail, M. N. \& Ismail, M. T. (2010). Analyzing of Virtual Private Network over Open source Application and Hardware Device Performance, International Journal Of Computational Cognition (http://www.ijcc.us) Vol. 8 No. 2. June 2010.

Neelakandan.B, dkk. (2010). Implementation of Automated Library Management System in the School of Chemistry Bharathidasan University using Koha Open source Software, International Journal Of Applied Engineering Research, Dindigul Volume 1 No1, 2010.

Santyasa, I W. (2009). Metode Penelitian Tindakan Kelas, Pengembangan, Korelasional, Kausal Komparatif, dan Eksperimen. Lembaga Penelitian Universitas Pendidikan Ganesha. Singaraja

Sulaeman, T. (2010). Satria Linux Variant Gnu/Linux Berbasis Ubuntu 10.04 Untuk Pembangunan Aplikasi. Program Studi IImu Komputer FPMIPA UPI Bandung.

Supriyatno, A. \& Romzi, M. (2006). E-Health Solusi Enterprise Bidang Kesehatan Berbasiskan Open source. Prosiding Konferensi Nasional Teknologi Informasi \& Komunikasi untuk Indonesia 3-4 Mei 2006.

Tănasie, C. A. (2010). Open source Web Content Management Systems Umbraco 
CMS. Open source Science Journal Vol. 2

No. 2, 2010. 